\title{
RELATIONSHIP BETWEEN ENVIRONMENTAL FACTORS AND METAZOOPLANKTON COMMUNITY STRUCTURE FROM ZHALONG NATIONAL NATURE RESERVE IN HEILONGJIANG PROVINCE, NORTHEASTERN CHINA
}

\author{
CHEN, Q. ${ }^{1,2}-$ SUN, X. $^{1}-$ YU, H. X. ${ }^{1 *}$ \\ ${ }^{I}$ College of Wildlife and Protected Area, Northeast Forestry University, Harbin 150040, China \\ ${ }^{2}$ Heilongjiang Wetland Protection and Digital Forestry Service Center, Harbin 150090, China \\ *Corresponding author \\ e-mail: china.yhx@163.com
}

(Received 29 Jul 2020; accepted $14^{\text {th }}$ May 2021)

\begin{abstract}
In the Zhalong National Nature Reserve in Heilongjiang Province of China, 24 sampling sites were set up in spring (May), summer (August) and autumn (October) of 2019. According to the hydrological conditions and sampling feasibility of the study area, metazooplankton, environmental factors and the correlation between metazooplankton functional groups and environmental factors were analysed and discussed. Results show that, a total of 52 species of metazooplankton were identified, including 36 species of rotifers belonging to 17 genera, 8 species of Cladocera and 2 orders of copepods. The metazooplankton can be divided into 7 functional groups: Rotifers filter feeders (RF), Rotifers carnivore (RC), Small copepods and claocera filter feeders (SCF), Middle copepods and claocera filter feeders (MCF), Middle copepods and claocera carnivore (MCC), Large copepods filter feeders (LCF) and Large copepods carnivore (LCC). The functional groups showed a seasonal succession pattern of $\mathrm{RF} / \mathrm{RC} / \mathrm{SCF} \rightarrow \mathrm{RF} / \mathrm{RC} / \mathrm{MCC} \rightarrow \mathrm{RF} / \mathrm{RC} / \mathrm{LCC}$. Redundancy Analysis (RDA) showing that The main water environmental factors affecting the distribution of metazooplankton functional groups were water temperature (WT), biological oxygen demand $\left(\mathrm{BOD}_{5}\right)$, ammonia nitrogen $\left(\mathrm{NH}_{3}-\mathrm{N}\right)$, total phosphorus (TP) and chloride ( $\mathrm{Cl}$-).
\end{abstract}

Keywords: Zhalong, wetland, zooplankton, impact, RDA

\section{Introduction}

Wetland covers only $6 \%$ of the earth's surface, which provides a living environment for $20 \%$ of the known species on the earth (Andrea et al., 2020; Biervliet et al., 2020; Lettoof et al., 2020; Tsai et al., 2020). It has irreplaceable ecological functions, so it enjoys the reputation of "kidney of the earth" (Chavan and Mutnuri, 2020; Cuthbert et al., 2020). A wetland ecosystem is a unique ecosystem formed by the interaction of land and water. It is one of the three most important ecosystems on earth (Taddeo and Dronova, 2020). It is composed of wetland plants, animals, microorganisms and environmental factors. It is also an important habitat for animals and plants and one of the most diverse ecological landscapes in nature (Duek et al., 2020). Wetland is located between water and land, because of its unique transitional nature in the ecosystem, it has eight ecological functions: natural reservoir, flood regulation and storage, groundwater supplement, coastal protection and erosion control, natural air conditioner and humidifier, carbon sink and carbon source, natural sewage treatment plant and cradle of life (Mahlatini et al., 2020). Due to economic development, urban expansion, industrial and agricultural pollution and human activities, wetland areas were rapidly reduced in size, causing serious ecological damage (Jabońska et al., 2020). 
Plankton is one of the main biological groups in wetland ecosystems. Because of their wide distribution and strong fecundity, they are the basis of other biological productivity in the water area (Brasil et al., 2020). Zooplankton, as the secondary producer of water ecosystem, plays an important role in the material cycle, energy flow and information transmission of the ecosystem. Its species composition, abundance, biomass and other community structure characteristics are important indicators for water environment quality evaluation (Sordino et al., 2020). As an indicator of water pollution, plankton plays an important role in water environmental biological monitoring; some plankton species play an important role in water environment biological monitoring Because of its ability to enrich radioisotopes, the substance can be used as an indicator of water contamination by radioisotopes (Flores et al., 2019). Therefore, the study of plankton is of great significance to evaluate the water quality of wetland, protect the biodiversity of wetland and ecological restoration of polluted water area. Therefore, it may become the main food source of the future world (Kosiba et al., 2018).

Metazooplankton is an important link in the circulation of freshwater ecosystem elements (Yuzhan et al., 2018). The up-down effect of metazooplankton fully reflects the feedback and negative feedback mechanism among the components of the aquatic ecosystem, and also determines the stability and balance of other trophic levels in the aquatic ecosystem (Palijan and Balkic, 2018). In the process of material circulation and energy flow, the changes of metazooplankton will directly or indirectly affect the horizontal distribution of other aquatic organisms in the same aquatic ecosystem, and play an important role in the material regulation of aquatic ecosystem (Velip and Rivonker, 2018). Eutrophication is one of the main reasons for the change of metazooplankton community structure, and the change of nutrients has a significant impact on its vertical distribution (Zhang et al., 2020). The species composition, community structure and species abundance of metazooplankton in a certain stage can reflect the quality of aquatic ecological environment. Therefore, metazooplankton is often used as one of the indicators of water environment monitoring and evaluation (Setubal and Riccardi, 2020). It is of great significance to improve water productivity, and has a close relationship with freshwater fish culture (Wu et al., 2008).

Zhalong National Nature Reserve, a wetland ecosystem nature reserve, affected by natural and human factors such as climate change, population increase, reclamation and expansion, factory sewage discharge and other natural and human factors ( $\mathrm{Wu}$ et al., 2014; Zou et al., 2010). The precipitation in the reserve and its surrounding basins has been reduced, the water environment has deteriorated, and the water quality in the reserve has also been polluted to a certain extent (Han et al., 2007). Therefore, this study discussed the composition and seasonal variation characteristics of metazooplankton functional groups, and the interaction between them and the physical and chemical factors of water environment, combined with the physical and chemical indexes and biological indexes, the water quality of the reserve was evaluated In order to provide basic data and scientific basis for water environment and biodiversity protection and rational development and utilization of Zhalong Nature Reserve.

\section{Materials and methods}

\section{Study area}

Zhalong National Nature Reserve $\left(46^{\circ} 52^{\prime} \mathrm{N}-47^{\circ} 32^{\prime} \mathrm{N}, 123^{\circ} 47^{\prime} \mathrm{E}-124^{\circ} 37^{\prime} \mathrm{E}\right)$ is located in the west of Heilongjiang Province and the lower reaches of Wuyuer River in 
Songnen Plain. It crosses Fuyu County, Tailai County, Tiefeng District, Ang'angxi District of Qiqihar City, and Lindian county and Duerbert Mongolian Autonomous County of Daqing City, with a total area of $2100 \mathrm{~km}^{2}$ Theme of rare birds and wetland ecological types of National Nature Reserve. In 1992, Zhalong National Nature Reserve was listed in the list of important wetlands in the world (Fig. 1).

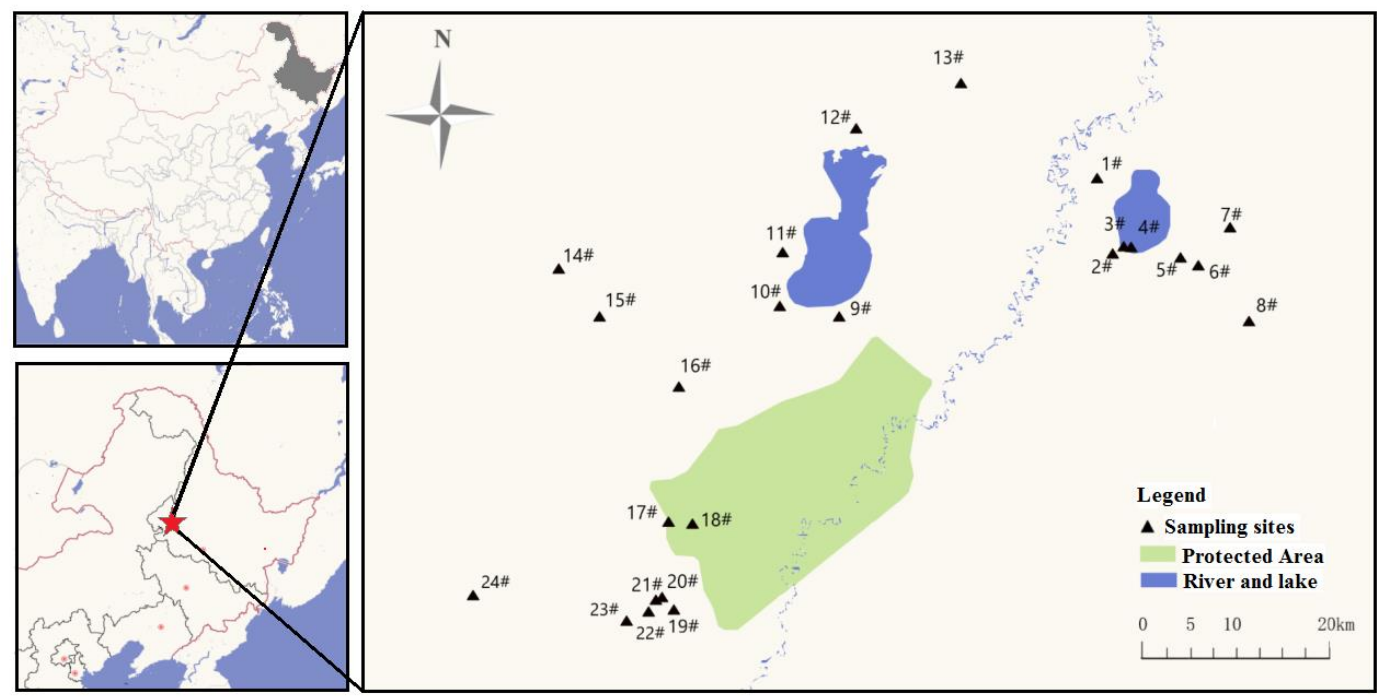

Figure 1. Map of sampling sites in Zhalong National Nature Reserve

\section{Environmental factors data sampling}

We collected all samples three times from 24 sampling sites in Zhalong National Nature Reserve in May, July and October periods for spring, summer and autumn in 2019 (Fig. 1; Table 1). At each sampling site, water temperature (WT), conductivity (EC), $\mathrm{pH}$, chloride $\left(\mathrm{Cl}^{-}\right)$and dissolved oxygen (DO) measured in the field using a portable multi-probe (YSI 6600, YSI Inc.). The concentration of ammonium nitrogen $\left(\mathrm{NH}_{3}-\mathrm{N}\right)$, nitrate nitrogen $\left(\mathrm{NO}_{3}{ }^{-}\right)$turbidity (TUR), total nitrogen $(\mathrm{TN})$, total phosphorus (TP) and biological oxygen demand $\left(\mathrm{BOD}_{5}\right)$ were measured according to the standard methods for China (MEP, 2002).

Table 1. Sampling sites coordination in Zhalong National Nature Reserve

\begin{tabular}{|c|c|c|c|}
\hline Sampling sites & Coordination $(\mathrm{E}, \mathrm{N})$ & Sampling sites & Coordination $(\mathrm{E}, \mathrm{N})$ \\
\hline $1 \#$ & $124^{\circ} 13^{\prime} 29^{\prime \prime}, 47^{\circ} 12^{\prime} 24^{\prime \prime}$ & 13\# & $124^{\circ} 18^{\prime} 55^{\prime \prime}, 47^{\circ} 16^{\prime} 47^{\prime \prime}$ \\
\hline 2\# & $124^{\circ} 13^{\prime} 5^{\prime \prime}, 47^{\circ} 10^{\prime} 44^{\prime \prime}$ & $14 \#$ & $124^{\circ} 17^{\prime} 7^{\prime \prime}, 47^{\circ} 18^{\prime} 9^{\prime \prime}$ \\
\hline $3 \#$ & $124^{\circ} 14^{\prime} 15^{\prime \prime}, 47^{\circ} 12^{\prime} 22^{\prime \prime}$ & $15 \#$ & $124^{\circ} 19^{\prime} 27^{\prime \prime}, 47^{\circ} 20^{\prime} 47^{\prime \prime}$ \\
\hline 4\# & $124^{\circ} 7^{\prime} 16^{\prime \prime}, 47^{\circ} 10^{\prime} 50^{\prime \prime}$ & $16 \#$ & $124^{\circ} 28^{\prime} 12^{\prime \prime}, 47^{\circ} 18^{\prime} 15^{\prime \prime}$ \\
\hline $5 \#$ & $124^{\circ} 12^{\prime} 9^{\prime \prime}, 47^{\circ} 10^{\prime} 17^{\prime \prime}$ & $17 \#$ & $124^{\circ} 27^{\prime} 58^{\prime \prime}, 47^{\circ} 18^{\prime} 17^{\prime \prime}$ \\
\hline $6 \#$ & $124^{\circ} 13^{\prime} 39^{\prime \prime}, 47^{\circ} 10^{\prime} 32^{\prime \prime}$ & $18 \#$ & $124^{\circ} 27^{\prime} 7^{\prime \prime}, 47^{\circ} 19^{\prime} 44^{\prime \prime}$ \\
\hline $7 \#$ & $124^{\circ} 13^{\prime} 17^{\prime \prime}, 47^{\circ} 10^{\prime} 48^{\prime \prime}$ & 19\# & $124^{\circ} 27^{\prime} 37^{\prime \prime}, 47^{\circ} 18^{\prime} 8^{\prime \prime}$ \\
\hline $8 \#$ & $124^{\circ} 12^{\prime} 51^{\prime},, 47^{\circ} 10^{\prime} 29^{\prime}$ & $20 \#$ & $124^{\circ} 29^{\prime} 46^{\prime \prime}, 47^{\circ} 18^{\prime} 3 ”$ \\
\hline 9\# & $124^{\circ} 9^{\prime} 59^{\prime \prime}, 47^{\circ} 17^{\prime} 48^{\prime \prime}$ & 21\# & $124^{\circ} 31^{\prime} 21^{\prime \prime}, 47^{\circ} 18^{\prime} 41^{\prime \prime}$ \\
\hline $10 \#$ & $124^{\circ} 11^{\prime} 18^{\prime \prime}, 47^{\circ} 16^{\prime} 47^{\prime \prime}$ & 22\# & $124^{\circ} 30^{\prime} 20^{\prime \prime}, 47^{\circ} 17^{\prime} 52^{\prime \prime}$ \\
\hline $11 \#$ & $124^{\circ} 13^{\prime} 49^{\prime \prime}, 47^{\circ} 15^{\prime} 17^{\prime \prime}$ & $23 \#$ & $124^{\circ} 31^{\prime} 57^{\prime \prime}, 47^{\circ} 16^{\prime} 41^{\prime \prime}$ \\
\hline $12 \#$ & $124^{\circ} 17^{\prime} 2^{\prime \prime}, 47^{\circ} 17^{\prime} 0^{\prime \prime}$ & $24 \#$ & $124^{\circ} 22^{\prime} 47^{\prime \prime}, 47^{\circ} 21^{\prime} 45^{\prime \prime}$ \\
\hline
\end{tabular}




\section{Metazooplankton data sampling}

We collected three random $20 \mathrm{~L}$ water at each sampling sites for metazooplankton samples and filtered through plankton net (Beijing Purity Instrument Co., LTD) with 64 $\mathrm{mm}$ mesh. Then subsamples fixed with formaldehyde solution with $4 \%$ concentration and transported to the laboratory for identification. In the laboratory, all samples were identified and counted with a light stereomicroscope (Leica Microsystems, Germany) following the species keys (Chiang and Du, 1979; Research Group of Carcinology, 1979; Wang, 1961). The metazooplankton biomass was calculated by using dry weight obtained from length-weight relationship of the filtered water volume (Sun et al., 2019). All samples were divided into 7 functional groups (FGs) according to Sun et al. (2019): Rotifers filter feeders (RF), Rotifers carnivore (RC), Small copepods and claocera filter feeders (SCF), Middle copepods and claocera filter feeders (MCF), Middle copepods and claocera carnivore (MCC), Large copepods filter feeders (LCF) and Large copepods carnivore (LCC) (Table 2).

\section{Data analysis}

Statistical analyses were carried out using the SPSS 19.0 software. Variation and correlation of environmental factors and metazooplankton FGs biomass in different sampling sites were analyzed by using One-way ANOVA. Relationship between metazooplankton FGs biomass and environmental factors was done using CANOCO 4.5 software. Before analysis, all data (except $\mathrm{pH})$ were transformed by $\lg (\mathrm{x}+1)$ to satisfy the normal distribution. The linear ordination method of the Redundancy Analysis (RDA) was used to reveal the relationship. Monte Carlo simulations with 499 permutations were used to test the significance of the environmental factors in explaining the metazooplankton FGs biomass in the RDA.

\section{Results and discussion}

\section{Environmental factors data characteristics}

Environmental factors of Zhalong National Nature Reserve were shown in Table 3. WT, $\mathrm{pH}, \mathrm{NH}_{3}-\mathrm{N}, \mathrm{NO}_{3}{ }^{-}$and $\mathrm{TP}$ were extremely significant differences $(P<0.01)$, and $\mathrm{Cl}^{-}$showed significant difference $(P<0.05)$. WT in autumn $(8.84 \pm 2.06)$ was significantly lower than that in spring and summer. The $\mathrm{pH}$ in summer $(9.26 \pm 0.39)$ was significantly lower than that in spring and autumn. TP in spring $(3.61 \pm 5.28)$ was significantly higher than that in summer and autumn. $\mathrm{Cl}^{-}$and $\mathrm{NO}_{3}{ }^{-}$were showed an increasing trend, while $\mathrm{NH}_{3}-\mathrm{N}$ decreased significantly from spring to autumn. Besides, Cond, TUR, DO, TN and $\mathrm{BOD}_{5}$ were no differences $(P>0.05)$. In the aquatic ecosystem, the water environment affects the biological population and community structure. Meanwhile, it plays a decisive role in the change of water quality (Hou et al., 2019; Divya et al., 2020; Munawar et al., 2020; Ozumchelouei et al., 2020).

\section{Metazooplankton data characteristics}

Meatzooplankton is an important part of aquatic ecosystem and plays an important role in ecosystem services (Tapia and Genzano, 2019; Cabrera et al., 2019; Uzundumlu et al., 2020). The dominant species have a high degree of ecological adaptability, which often determines the environmental conditions within the 
community to a large extent, so it has a great impact on the survival and growth of other species (Naumenko and Telesh, 2019; Pinheiro-Silva et al., 2020). In Zhalong National Nature Reserve, we found 9 dominant metazooplankton species, including 7 rotifers (Asplanchna brightwel, Asplachna priodonta, Brachionus angularis, Brachionus calyciflorus, Keratella cochlearis, Trichocerca pusilla and Polyarthra trigla) and 2 copepods (Nauplii and Thermocyclops hyalinus) (Table 4). In Figure 2, mean metazooplankton biomass is $1.79 \mathrm{mg} / \mathrm{L}$, the highest biomass observed at 23\# sampling site, and the lowest at 11\# sampling site. The results of one-way ANOVA showed that there was significant seasonal variation of metazooplankton biomass in Zhalong Nature Reserve $(\mathrm{P}=0.001)$.

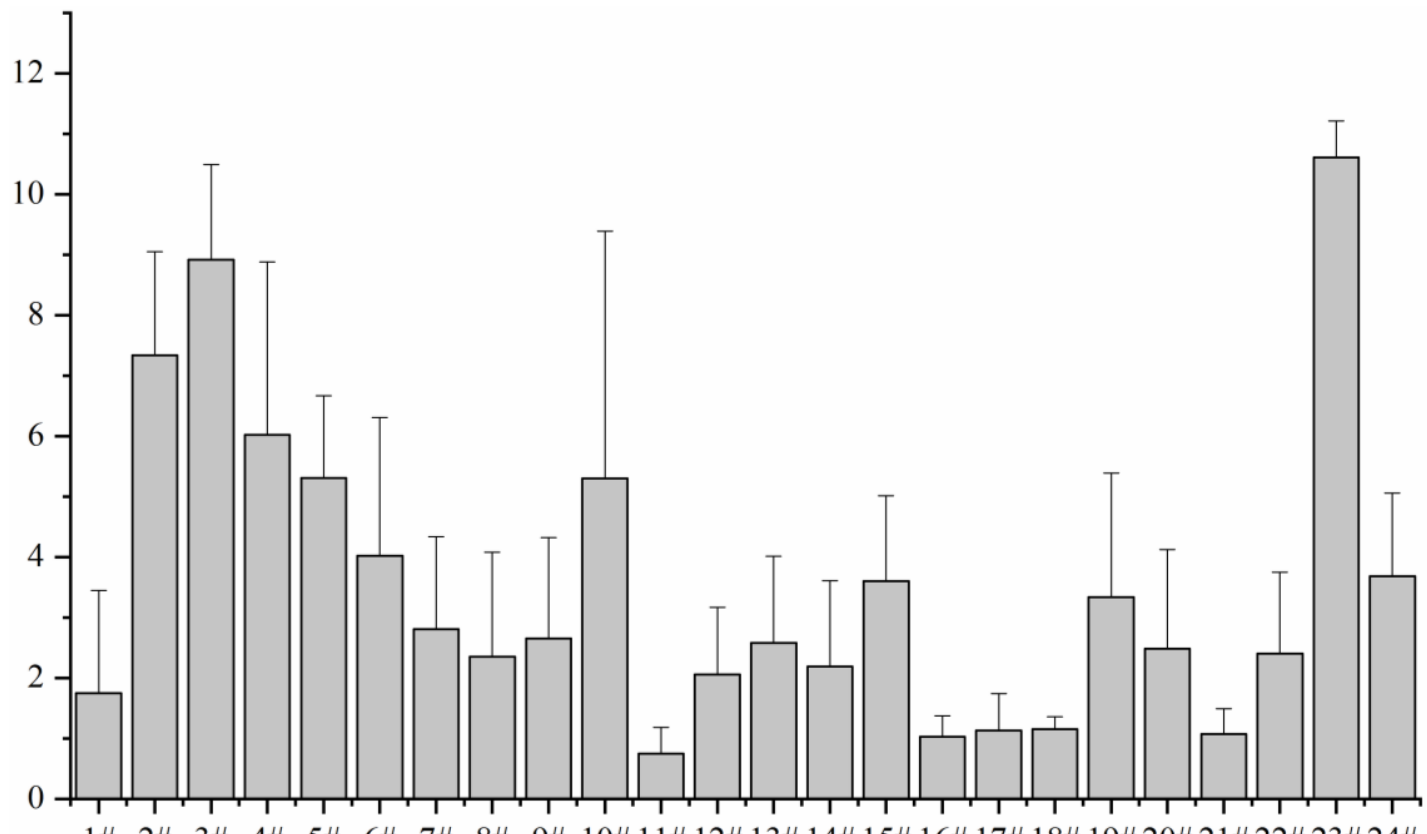

$1 \#$ 2\# $3 \# 4 \# 5 \#$ 6\# $7 \#$ 8\# 9\# 10\#11\#12\#13\#14\#15\#16\#17\#18\#19\#20\#21\#22\#23\#24\#

Figure 2. Biomass ( $\mathrm{mg} / \mathrm{L})$ of metazooplankton in Zhalong National Nature Reserve. Error bars mean standard error

Table 2. Descriptor metazooplankton functional groups (FGs) in freshwater ecosystem

\begin{tabular}{c|c|c}
\hline FGs & Body size (mm) & Feeding habits \\
\hline Rotifers filter feeders (RF) & & $\begin{array}{c}\text { A predter eater that feeds on bacteria, algae, and } \\
\text { organic matter }\end{array}$ \\
\hline $\begin{array}{c}\text { Rotifers carnivore (RC) } \\
\text { and small crustaceans }\end{array}$ \\
\hline $\begin{array}{c}\text { Small copepods and claocera filter } \\
\text { feeders (SCF) }\end{array}$ & $<0.7$ & $\begin{array}{c}\text { A filter eater that feeds on bacteria, algae, organic } \\
\text { matter, and protozoa }\end{array}$ \\
\hline $\begin{array}{c}\text { Middle copepods and claocera filter } \\
\text { feeders (MCF) }\end{array}$ & $0.7-1.5$ & $\begin{array}{c}\text { A filter eater that feeds on bacteria, algae, organic } \\
\text { matter, and protozoa }\end{array}$ \\
\hline $\begin{array}{c}\text { Middle copepods and claocera } \\
\text { carnivore (MCC) }\end{array}$ & $0.7-1.5$ & $\begin{array}{c}\text { A predator that feeds on rotifers, clades, diptera } \\
\text { (chironomid larvae), and oligochaetes }\end{array}$ \\
\hline $\begin{array}{c}\text { Large copepods filter feeders (LCF) } \\
\text { Large copepods carnivore (LCC) }\end{array}$ & $>1.5$ & $\begin{array}{c}\text { A filter eater that feeds on bacteria, algae, organic } \\
\text { matter, and protozoa }\end{array}$ \\
\hline
\end{tabular}




$$
-2848-
$$

Table 3. The values (mean $\pm S D$ ) of environmental factors among sampling sites. Water temperature (WT), conductivity $(\mathrm{EC})$, $\mathrm{pH}$, chloride $\left(\mathrm{Cl}^{-}\right)$, ammonium nitrogen $\left(\mathrm{NH}_{3}-\mathrm{N}\right)$, nitrate nitrogen $\left(\mathrm{NO}_{3}{ }^{-}\right)$turbidity (TUR), dissolved oxygen (DO), total nitrogen (TN), total phosphorus $(T P)$ and biological oxygen demand $\left(B O D_{5}\right)$, p values from One-way ANOVA tested by post-hoc test using Tukey HSD ANOVA

\begin{tabular}{c|c|c|c|c}
\hline & Spring & Summer & Autumn & $\boldsymbol{p}$ \\
\hline $\mathrm{WT}\left({ }^{\circ} \mathrm{C}\right)$ & $17.89 \pm 2.21$ & $23.68 \pm 2.81$ & $8.84 \pm 2.06$ & $0.000^{* *}$ \\
$\mathrm{Cond}(\mathrm{ms} / \mathrm{m})$ & $0.5 \pm 0.51$ & $0.65 \pm 0.7$ & $0.37 \pm 0.32$ & 0.205 \\
$\mathrm{pH}$ & $9.46 \pm 0.38$ & $9.26 \pm 0.39$ & $9.63 \pm 0.42$ & $0.008^{* *}$ \\
$\mathrm{Cl}^{-}(\mathrm{mg} / \mathrm{L})$ & $38.22 \pm 21.12$ & $73.27 \pm 113.52$ & $114.24 \pm 130.78$ & $0.044^{*}$ \\
$\mathrm{NH}_{3}-\mathrm{N}(\mathrm{mg} / \mathrm{L})$ & $60.1 \pm 34.65$ & $31.84 \pm 17$ & $16.37 \pm 9.67$ & $0.000^{* *}$ \\
$\mathrm{NO}_{3}^{-}(\mathrm{mg} / \mathrm{L})$ & $17.93 \pm 9.24$ & $50.23 \pm 25.63$ & $269.42 \pm 287.42$ & $0.000^{* *}$ \\
$\mathrm{TUR}(\mathrm{NTU})$ & $8.28 \pm 9.16$ & $14.32 \pm 19.06$ & $13.55 \pm 16.79$ & 0.365 \\
$\mathrm{DO}(\mathrm{mg} / \mathrm{L})$ & $6.9 \pm 2.16$ & $7.63 \pm 2.41$ & $9.79 \pm 1.9$ & 0.107 \\
$\mathrm{TN}(\mathrm{mg} / \mathrm{L})$ & $2.18 \pm 1.27$ & $1.25 \pm 1.15$ & $2.48 \pm 1.34$ & 0.239 \\
$\mathrm{TP}(\mathrm{mg} / \mathrm{L})$ & $3.61 \pm 5.28$ & $0.52 \pm 0.5$ & $0.57 \pm 0.45$ & $0.001^{* *}$ \\
$\mathrm{BOD} 5(\mathrm{mg} / \mathrm{L})$ & $1.56 \pm 0.24$ & $2.29 \pm 0.2$ & $2.79 \pm 0.21$ & 0.166 \\
\hline
\end{tabular}

${ }^{*} p<0.05$

${ }^{* *} p<0.01$

We totally identified 3 taxonomic and 52 species of metazooplankton consist of 36 rotifers $(69 \%), 8$ cladocera $(15.5 \%)$ and 8 copepods (15.5\%). Metazooplankton were divided into predators and filter feeders according to their feeding habits (Shi et al., 2015; Mwagona et al., 2018; Ma et al., 2019; Gholizadeh et al., 2019). Combined with body size and the interaction between metazooplankton, seven functional groups in freshwater ecosystem was divided into Rotifer filter feeders (RF), Rotifer carnivore (RC), Small copepods and claocera filter feeders (SCF), Middle copepods and claocera filter feeders (MCF), Middle copepods and claocera carnivore (MCC), Large copepods filter feeders (LCF) and Large copepods carnivore (LCC) (Table 5).

Zooplankton is an important part of aquatic ecosystem, and its biomass research is of great significance (Jiang et al., 2020; Romero et al., 2020; Rocha et al., 2019; Cabrera et al., 2019).

Table 4. Dominant species and their dominances from Zhalong National Nature Reserve

\begin{tabular}{c|c|c|c}
\hline \multirow{2}{*}{ Dominant species } & \multicolumn{3}{|c}{ Dominance (Li et al., 2019) } \\
\cline { 2 - 4 } & Spring & Summer & Autumn \\
\hline Asplanchna brightwel & 0.03 & 0.02 & - \\
Asplachna priodonta & 0.07 & 0.07 & 0.1 \\
Brachionus angularis & 0.18 & 0.14 & 0.18 \\
Brachionus calyciflorus & - & 0.04 & 0.09 \\
Keratella cochlearis & 0.06 & 0.06 & 0.08 \\
Trichocerca pusilla & 0.04 & 0.03 & 0.04 \\
Polyarthra trigla & - & 0.04 & 0.05 \\
Nauplii & 0.14 & 0.09 & - \\
Thermocyclops hyalinus & 0.03 & 0.04 & - \\
\hline
\end{tabular}


Table 5. Composition of metazooplankton functional groups in Zhalong National Nature Reserve. Rotifers filter feeders (RF), Rotifers carnivore (RC), Small copepods and claocera filter feeders (SCF), Middle copepods and claocera filter feeders (MCF), Middle copepods and claocera carnivore (MCC), Large copepods filter feeders (LCF) and Large copepods carnivore ( $L C C)$

\begin{tabular}{|c|c|c|}
\hline Taxonomic & Species & FGs \\
\hline \multirow{36}{*}{ Rotifera } & Rotaria neptunia & $\mathrm{RF}$ \\
\hline & Asplanchna brightwel & $\mathrm{RC}$ \\
\hline & Asplachna priodonta Gosse & $\mathrm{RC}$ \\
\hline & Colurella obtusa & $\mathrm{RF}$ \\
\hline & Colurella adriatica & $\mathrm{RF}$ \\
\hline & Conochilus unicornis & $\mathrm{RF}$ \\
\hline & Brachionus angularis & $\mathrm{RF}$ \\
\hline & Brachionus calyciflorus Pallas & $\mathrm{RF}$ \\
\hline & Brachionus forficula & $\mathrm{RF}$ \\
\hline & Brachionus leydigi & $\mathrm{RF}$ \\
\hline & Brachionus diversicornis & $\mathrm{RF}$ \\
\hline & Brachionus quadridentatus & $\mathrm{RF}$ \\
\hline & Keratella cochlearis & $\mathrm{RF}$ \\
\hline & Keratella valga & $\mathrm{RF}$ \\
\hline & Keratella guadrata & $\mathrm{RF}$ \\
\hline & Notholon sqwmoda & $\mathrm{RF}$ \\
\hline & Lecane buna & $\mathrm{RF}$ \\
\hline & Lecane ungulata & $\mathrm{RF}$ \\
\hline & Monostyla lunaris & $\mathrm{RF}$ \\
\hline & Monostyla bulla & $\mathrm{RF}$ \\
\hline & Monostyla closterocerca & $\mathrm{RF}$ \\
\hline & Monostyla pyriformis & $\mathrm{RF}$ \\
\hline & Scaridium longicaudum & $\mathrm{RF}$ \\
\hline & Trichocerca bicristata & $\mathrm{RF}$ \\
\hline & Trichocerca longiseta & $\mathrm{RF}$ \\
\hline & Trichocerca capucina & $\mathrm{RF}$ \\
\hline & Trichocerca pusilla & $\mathrm{RF}$ \\
\hline & Diurella weberi & $\mathrm{RF}$ \\
\hline & Chromogaster ovalis & $\mathrm{RF}$ \\
\hline & Polyarthra trigla & $\mathrm{RC}$ \\
\hline & Gastropus hyptopus & $\mathrm{RF}$ \\
\hline & Filinia longiseta & $\mathrm{RF}$ \\
\hline & Pompholyx sulcata & $\mathrm{RF}$ \\
\hline & Pompholyx complanata & $\mathrm{RF}$ \\
\hline & Collotheca pelagica & $\mathrm{RF}$ \\
\hline & Euchlanis lyra Hudson & $\mathrm{RF}$ \\
\hline \multirow{8}{*}{ Cladocera } & Diaphanosoma leuchtenbergianum & $\mathrm{MCF}$ \\
\hline & Daphnia longispina & LCF \\
\hline & Daphnia hyalina & MCF \\
\hline & Moina micrura & LCF \\
\hline & Bosmina longirostris & $\mathrm{MCF}$ \\
\hline & Alona rectangular Sars & $\mathrm{SCF}$ \\
\hline & Alona quadrongularia & $\mathrm{SCF}$ \\
\hline & Chydorus sphaericus & SCF \\
\hline \multirow{8}{*}{ Copepoda } & Sinocalanus tenellus & $\mathrm{MCF}$ \\
\hline & Cyclops vicinus & $\mathrm{MCF}$ \\
\hline & Nauplii & $\mathrm{SCF}$ \\
\hline & Eucyclops serrulatus & MCF \\
\hline & Sinodiaptomus sarsi & $\mathrm{LCC}$ \\
\hline & Eucyclops speratus & $\mathrm{MCF}$ \\
\hline & Thermocyclops hyalinus & $\mathrm{MCC}$ \\
\hline & Thermocyclops dybowskii & $\mathrm{MCC}$ \\
\hline
\end{tabular}


In spring, the biomass of metazooplankton functional groups was higher in sampling sites 23\#, 2\# and 3\#. Among the sampling sites 1\#, 13\#, 14\# and 20\#, the functional group RF was dominant; the functional group RC was dominant at 9\#, 10\#, 11\# and 18\# sampling sites; SCF and RF were dominant in 16\# sampling sites; RF and RC were dominant in other sampling sites (Fig. 3).

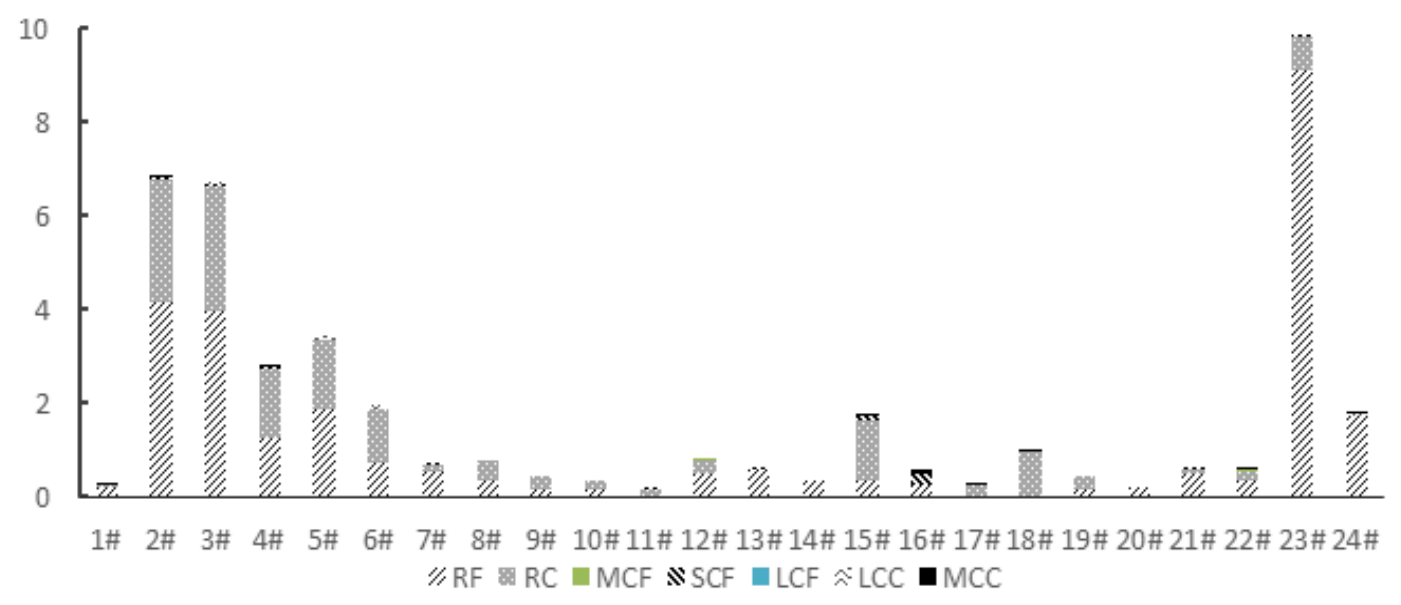

Figure 3. Metazooplankton functional groups biomass $(\mathrm{mg} / \mathrm{L})$ of Zhalong National Nature Reserve in spring. Rotifers filter feeders (RF), Rotifers carnivore (RC), Small copepods and claocera filter feeders (SCF), Middle copepods and claocera filter feeders $(M C F)$, Middle copepods and claocera carnivore (MCC), Large copepods filter feeders (LCF), and Large copepods carnivore (LCC)

In summer, the biomass of metazooplankton functional groups was higher in sampling sites 10\#, 23\#, 2\#, 3\# and 4\#. Functional groups RF were dominant in 1\#, 13\#, 14\#, 20\# and 24\# sampling sites, RC was dominant in 11\#, 17\# and 18\# sampling sites, RF, RC and LCC were dominant in 15\# sampling sites, RF, SCF and MCC were dominant in 16\# sampling sites, and RF and RC were dominant in other sampling sites (Fig. 4).

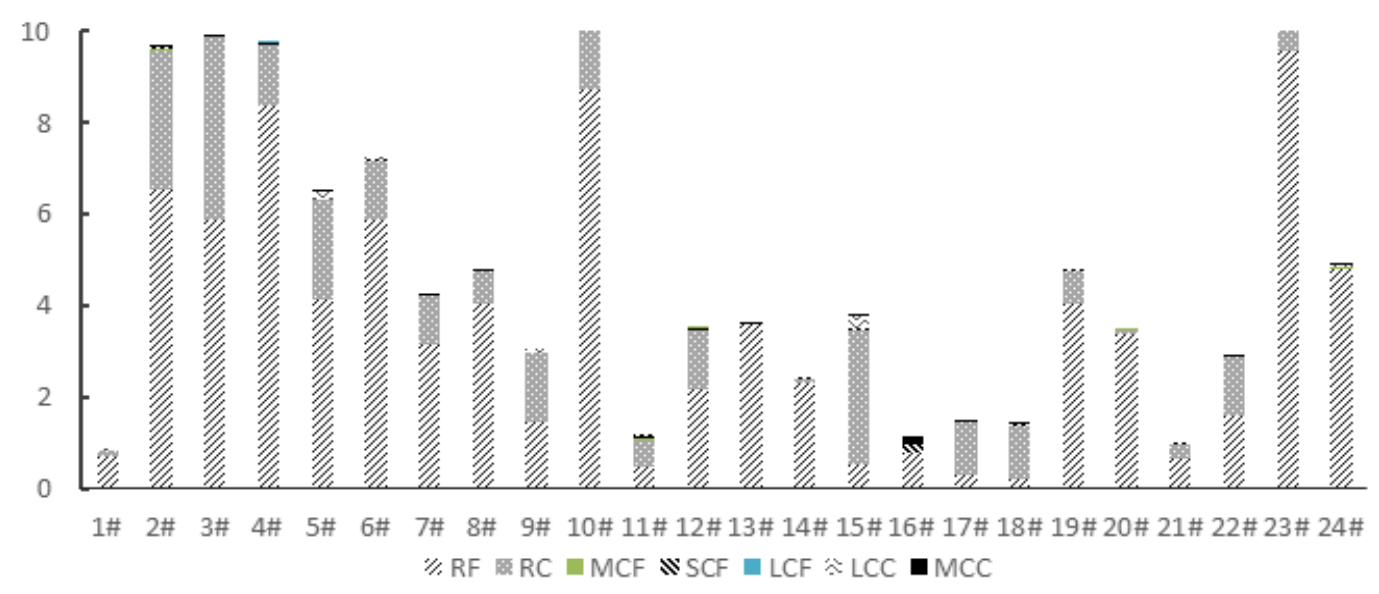

Figure 4. Metazooplankton functional groups biomass $(\mathrm{mg} / \mathrm{L})$ of Zhalong National Nature Reserve in summer. Rotifers filter feeders (RF), Rotifers carnivore (RC), Small copepods and claocera filter feeders (SCF), Middle copepods and claocera filter feeders (MCF), Middle copepods and claocera carnivore (MCC), Large copepods filter feeders (LCF), and Large copepods carnivore (LCC) 
In autumn, the biomass of metazooplankton functional groups was higher in sampling sites $3 \#$ and 23\#. Among the 12\# sampling sites, the functional group RC was dominant, while the functional group RF was dominant in 13\#, 20\#, 23\# and 24\# sampling sites, RF and MCC were dominant in 1\# and 16\# sampling sites, and RF and $\mathrm{RC}$ were dominant in other sampling sites (Fig. 5).

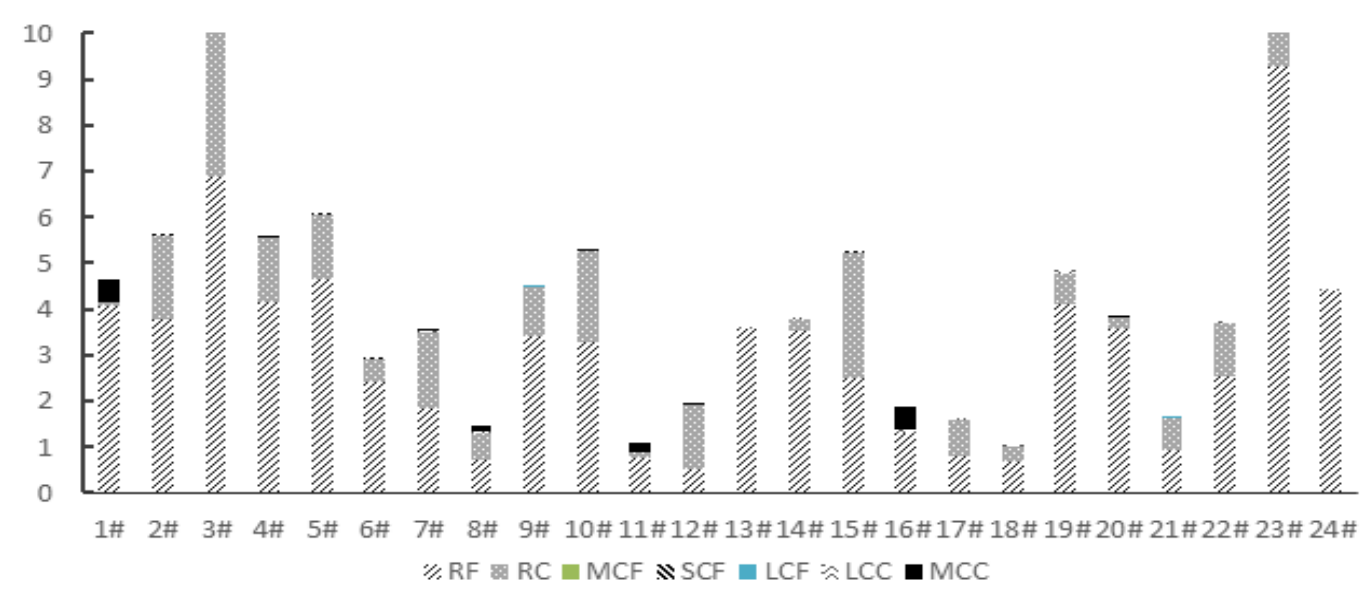

Figure 5. Metazooplankton functional groups biomass $(\mathrm{mg} / \mathrm{L})$ of Zhalong National Nature Reserve in autumn. Rotifers filter feeders (RF), Rotifers carnivore (RC), Small copepods and claocera filter feeders (SCF), Middle copepods and claocera filter feeders (MCF), Middle copepods and claocera carnivore (MCC), Large copepods filter feeders (LCF), and Large copepods carnivore (LCC)

If the biomass of metazooplankton functional group is more than $10 \%$ of the total biomass, it is called the dominant functional group. As the dominant species aggregation in the survey period, the dominant functional group can best reflect the water environment of the study area (Zaghloul et al., 2020; Sharma and Sharma, 2020; Macmillan et al., 2019). In spring, RF, RC and SCF were dominant, accounting for $45.76 \%, 33.2 \%$ and $11.41 \%$ respectively. In summer, RF, RC and MCC were dominant, accounting for $71 \%, 23.78 \%$ and $2.81 \%$ respectively. In autumn, RF, RC and LCC were dominant, accounting for $64.76 \%, 27.35 \%$ and $5.83 \%$ respectively. The average biomass of metazooplankton functional groups in Zhalong Nature Reserve was arranged from high to low in different seasons. The results showed that summer $(0.70$ $\mathrm{mg} / \mathrm{L})>$ autumn $(0.41 \mathrm{mg} / \mathrm{L})>\operatorname{spring}(0.26 \mathrm{mg} / \mathrm{L})$ (Fig. 6).

\section{Correlation analysis between metazooplankton FGs biomass and environmental factors}

Environmental conditions have a great influence on the growth of metazooplankton (Kang et al., 2008; Qing et al., 2010; Tutasi and Escribano, 2019; Meng and Li, 2020). It can be seen from Table 6 that the biomass of metazooplankton functional groups has obvious correlation with water environmental factors except RC. RF was negatively correlated with WT $(P<0.01)$ and TN $(P<0.05)$, while positively correlated with BOD5 $(P<0.01)$. MCF and LCC were both negatively correlated with WT $(P<0.05)$. SCF was positively correlated with $\mathrm{NH}_{3}-\mathrm{N}(P<0.01)$ and TP $(P<0.01)$, while negatively correlated with $\mathrm{NO}_{3}^{-}(P<0.05)$ and DO $(P<0.05)$. LCF was negatively correlated with WT $(P<0.05)$ and TN $(P<0.05)$. MCC was positively correlated with $\mathrm{Cl}^{-}(P<0.01)$. 


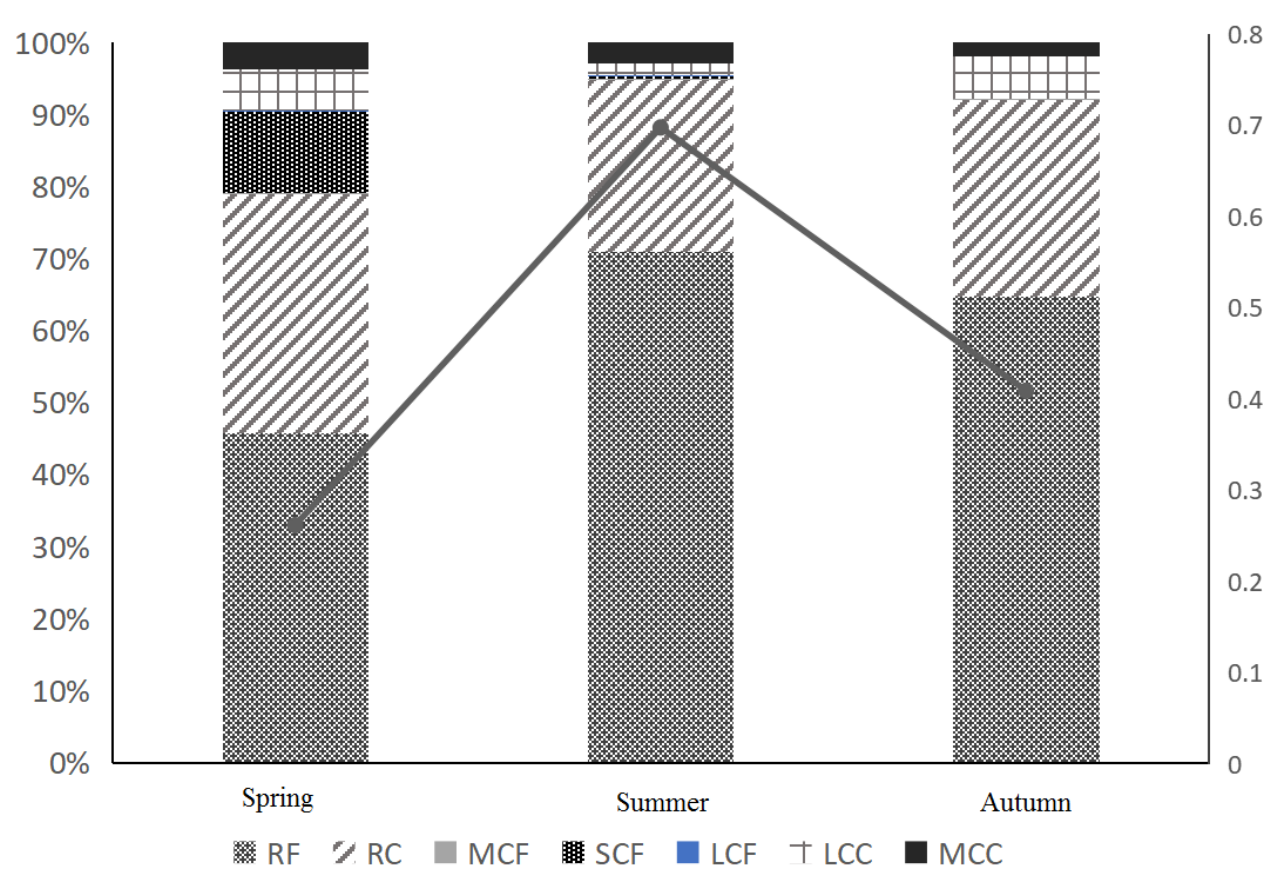

Figure 6. Metazooplankton functional groups relatively biomass (\%) and average biomass $(\mathrm{mg} / \mathrm{L})$ among seasons of Zhalong National Nature Reserve. Rotifers filter feeders $(R F)$,

Rotifers carnivore (RC), Small copepods and claocera filter feeders (SCF), Middle copepods and claocera filter feeders (MCF), Middle copepods and claocera carnivore (MCC), Large copepods filter feeders ( LCF), and Large copepods carnivore ( $L C C)$

Table 6. Pearson correlation analysis of between metazooplankton FGs biomass and environmental factors. Metazooplankton FGs: Rotifers filter feeders (RF), Rotifers carnivore $(R C)$, Small copepods and claocera filter feeders (SCF), Middle copepods and claocera filter feeders (MCF), Middle copepods and claocera carnivore (MCC), Large copepods filter feeders $(L C F)$ and Large copepods carnivore (LCC). Environmental factors: Water temperature (WT), conductivity (Cond), $\mathrm{pH}$, chloride $\left(\mathrm{Cl}^{-}\right)$, ammonium nitrogen $\left(\mathrm{NH}_{3}-\mathrm{N}\right)$, nitrate nitrogen $\left(\mathrm{NO}_{3}{ }^{-}\right)$turbidity $(\mathrm{TUR})$, dissolved oxygen $(\mathrm{DO})$, total nitrogen $(\mathrm{TN})$, total phosphorus $(T P)$ and biological oxygen demand $\left(B O D_{5}\right)$

\begin{tabular}{|c|c|c|c|c|c|c|c|c|c|c|c|}
\hline & WT & Cond & $\mathrm{Cl}^{-}$ & $\mathrm{NH}_{3}-\mathrm{N}$ & $\mathrm{NO}_{3}{ }^{-}$ & NTU & DO & TN & TP & BOD5 & pH \\
\hline $\mathrm{RF}$ &.$- .328^{* *}$ & 219 & .022 & 103 & 002 & 92 & .202 & $.254^{*}$ & 14 & $342^{* *}$ & 42 \\
\hline $\mathrm{RC}$ & -0 & & -0.01 & 057 & 4 & 56 & 04 & .214 & -0.084 & .181 & 3 \\
\hline MCF & $-.264^{*}$ & 18 & -0.193 & 25 & 219 & 0.033 & -0.217 & -0.208 & 0.085 & 0.051 & -0.03 \\
\hline SCF & -0.071 & 0.111 & -0.163 & $.334^{* *}$ & $-.260^{*}$ & -0.017 & $-.258^{*}$ & -0.019 & $.408^{* * *}$ & -0.125 & -0.085 \\
\hline LCF & $-.250^{*}$ & 0.135 & 0.009 & -0.028 & -0.087 & 0.091 & -0.192 & $-.251^{*}$ & 0.03 & 0.134 & -0.117 \\
\hline LCC & $-.267^{*}$ & 0.214 & -0.102 & 0.071 & -0.031 & 0.066 & -0.194 & -0.167 & 0.023 & 0.028 & -0.148 \\
\hline $\mathrm{MCC}$ & 0.032 & -0.09 & .338 $^{* * *}$ & -0.127 & 0.145 & 0.107 & 0.146 & 0.225 & -0.036 & 0.216 & -0.003 \\
\hline
\end{tabular}

${ }_{* * *}^{*}<0.05$

$* * 0<0.01$

First of all, after detrend correspondence analysis (DCA) of metazooplankton functional group biomass data, it was found that the maximum gradient of ordination axis was 1.77, less than 3. Therefore, linear model sequencing analysis (RDA) was carried out for metazooplankton functional groups and environmental factors (Wang et 
al., 2016; Sun et al., 2019; Wu et al., 2019; Saler et al., 2019). From Table 7, eigenvalues of Axis1 and Axis2 were 0.076 and 0.061, respectively. FGs-environment correlations of Axis 1 and Axis2 were 0.581 and 0.511 , respectively. The first two axes account for $13.7 \%$ of FGs data relation.

In aquatic ecosystem, the community structure and its changes of metazooplankton are the result of the action of many environmental factors in time series (Cryer et al., 1986; Tavernini et al., 2005; Li et al., 2013; Huo et al., 2020; Zamora-Barrios et al., 2019). Figure 7 shows the RDA sequence diagram of the metazooplankton functional groups and water environmental factors in Zhalong National Nature Reserve, where the environmental factors are represented by the red solid line with a hollow arrow, and the functional group is represented by a solid line with a solid arrow. The most relevant positive environmental factors of Axis 1 were TP (0.5763), and the negative environmental factors were DO (-0.5382) and $\mathrm{Cl}^{-}(-0.3944)$. The positive environmental factors related to axis 2 were Cond (0.5728) and $\mathrm{BOD}_{5}(0.4849)$, while the negative environmental factors were TN (- 0.4739) and WT (- 0.6397). RF, RC and LCF were positively correlated with TUR, Cond and $\mathrm{BOD}_{5}$, negatively correlated with $\mathrm{TN}$ and WT; MCF, SCF and MCC were positively correlated with $\mathrm{TP}, \mathrm{NH}_{3}-\mathrm{N}$, Cond, and $\mathrm{NO}_{3}{ }^{-}$, $\mathrm{Cl}^{-}$and DO. LCC was positively correlated with $\mathrm{NO}_{3}{ }^{-}$and TUR, and negatively correlated with TP and $\mathrm{NH}_{3}-\mathrm{N}$.

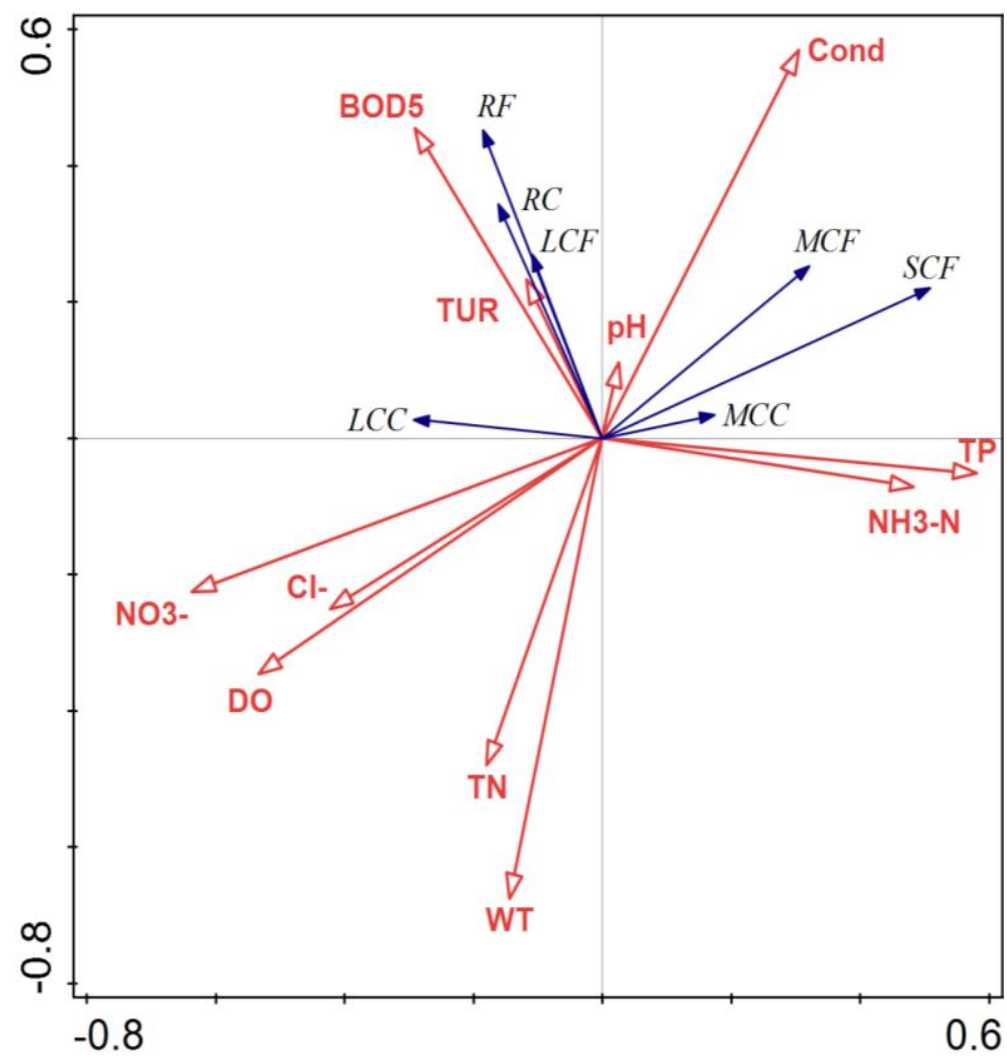

Figure 7. RDA bioplot of metazooplankton FGs and environmental factors. Metazooplankton FGs: Rotifers filter feeders (RF), Rotifers carnivore (RC), Small copepods and claocera filter feeders (SCF), Middle copepods and claocera filter feeders (MCF), Middle copepods and claocera carnivore (MCC), Large copepods filter feeders (LCF) and Large copepods carnivore ( $L C C)$. Environmental factors: Water temperature (WT), conductivity $(\mathrm{EC}), \mathrm{pH}$, chloride $\left(\mathrm{Cl}^{-}\right)$, ammonium nitrogen $\left(\mathrm{NH}_{3}-\mathrm{N}\right)$, nitrate nitrogen $\left(\mathrm{NO}_{3}^{-}\right)$turbidity $(\mathrm{TUR})$, dissolved oxygen $(\mathrm{DO})$, total nitrogen $(T N)$, total phosphorus $(T P)$ and biological oxygen demand $\left(B O D_{5}\right)$ 


$$
\text { - } 2854 \text { - }
$$

Table 7. RDA results of metazooplankton FGs biomass

\begin{tabular}{c|c|c|c|c}
\hline Axes & $\mathbf{1}$ & $\mathbf{2}$ & $\mathbf{3}$ & $\mathbf{4}$ \\
\hline Eigenvalues & 0.076 & 0.061 & 0.033 & 0.026 \\
FGs-environment correlations & 0.581 & 0.511 & 0.436 & 0.381 \\
Cumulative percentage variance of FGs data & 7.6 & 13.7 & 17.0 & 20.0 \\
Cumulative percentage variance of FGs-environment relation & 35.9 & 64.3 & 79.8 & 91.6 \\
\hline
\end{tabular}

\section{Conclusion}

In our study, we found 52 species of metazooplankton from Zhalong National Nature Reserve, including 36 species of Rotifera, eight species of Cladocera and eight species of Copepoda. They belong to seven functional groups (RF, RC, MCF, SCF, LCF, LCC and $\mathrm{MCC}$ ), and seasonal succession is $\mathrm{RF} / \mathrm{RC} / \mathrm{SCF} \rightarrow \mathrm{RF} / \mathrm{RC} / \mathrm{MCC} \rightarrow \mathrm{RF} / \mathrm{RC} / \mathrm{LCC}$. Environmental factors of $\mathrm{WT}, \mathrm{pH}, \mathrm{NH}_{3}-\mathrm{N}, \mathrm{NO}_{3}{ }^{-}$and $\mathrm{TP}$ were extremely significant differences $(P<0.01)$, and $\mathrm{Cl}^{-}$showed significant difference $(P<0.05)$. The main environmental factors are $\mathrm{WT}, \mathrm{BOD}_{5}, \mathrm{NH}_{3}-\mathrm{N}, \mathrm{TP}$ and $\mathrm{Cl}^{-}$. We strongly suggest that the monitoring of these environmental factors should be strengthened to ensure the stability of zooplankton community structure in the future study.

Acknowledgements. We sincerely acknowledge the National Key Research and Development Program of China (2016YFC0500406).

\section{REFERENCES}

[1] Andrea, E. N., Ghia, T., Moretta-Urdiales, M. M., Moreira, N. M. (2020): Feeding habits of Anolis sagrei, an introduced species, in urban ecosystems of Guayas province. - Urban Ecosystems 23: 1371-1376.

[2] Biervliet, O. V., Mcinnes, R. J., Lewis-Phillips, J., Tosney, J. (2020): Can an integrated constructed wetland in Norfolk reduce nutrient concentrations and promote in situ bird species richness? - Wetlands 40: 967-981.

[3] Brasil, J., Santos, J. B. O., Sousa, W., Menezes, R. F., Huszar, V. L. M., José, L. A. (2020): Rainfall leads to habitat homogenization and facilitates plankton dispersal in tropical semiarid lakes. - Aquatic Ecology 54(1): 225-241.

[4] Cabrera, S., Compte, J., Stéphanie Gascón, Boix, D., Quintana, X. D. (2019): How do zooplankton respond to coastal wetland restoration? The case of newly created salt marsh lagoons in La Pletera (NE Catalonia). - Limnetica 38(2): 721-741.

[5] Chavan, R., Mutnuri, S. (2020): Domestic wastewater treatment by constructed wetland and microalgal treatment system for the production of value-added products. Environmental Technology. https://doi.org/10.1080/09593330.2020.1726471.

[6] Chiang, S. C., Du, N. S. (1979): Fauna Sinica, Crustacea, Freshwater Cladocera. Science Press, Beijing (in Chinese).

[7] Cryer, M., Peirson, G., Townsend, C. R. (1986): Reciprocal interactions between roach, rutilus, and zooplankton in a small lake: prey dynamics and fish growth and recruitment. Limnology and Oceanography 31(5): 1022-1038.

[8] Cuthbert, R. N., Dalu, T., Wasserman, R. J., Weyl, O. L. F., Froneman, P. W., Callaghan, A. (2020): Sex demographics alter the effect of habitat structure on predation by a temporary pond specialist. - Hydrobiologia 847(3): 831-840.

[9] Divya, K. R., Zhao, S., Chen, Y., Cheng, F., Xie, S. (2020): A comparison of zooplankton assemblages in Nansi Lake and Hongze Lake, potential influences of the east route of the 
south-to-north water transfer project, China. - Journal of Oceanology and Limnology 39: 623-636.

[10] Duek, J., Daenová, E., Pavelka, M., Marek, M. V. (2020): Methane and Carbon Dioxide Release from Wetland Ecosystems. - In: Vara Prasad, M. N., Pietrzykowski, M. (eds.) Climate Change and Soil Interactions. Elsevier, Amsterdam, pp. 509-553.

[11] Flores, H., David, C., Ehrlich, J., Hardge, K., Kohlbach, D., Lange, B. A. (2019): Sea-ice properties and nutrient concentration as drivers of the taxonomic and trophic structure of high-arctic protist and metazoan communities. - Polar Biology 42(7): 1-19.

[12] Gholizadeh, M., Patimar, R., Raeji, H., Porsofi, T. (2019): Investigating the density and frequency of zooplankton in the southeastern basin of the Caspian Sea (Gorgan Bay). Iranian Journal of Fisheries Sciences 28(2): 59-70.

[13] Han, M., Sun, Y., Xu, S. (2007): Characteristics and driving factors of marsh changes in Zhalong Wetland of China. - Environmental Monitoring and Assessment 127(1-3): 363381.

[14] Hou, W., Sun, S. H., Gu, B. H., Sun, L., Jia, R. B. (2019): Stable isotopes of zooplankton and their applications in the research of aquatic ecosystems. - The Journal of Applied Ecology 30(6): 1807-1814 (in Chinese with English abstract).

[15] Huo, Y., Liu, Q., Zhang, F., Li, C., Sun, S. (2020): Biomass and estimated production, and feeding pressure on zooplankton of Chaetognaths in the Yellow Sea, China. Terrestrial Atmospheric and Oceanic Sciences 31(1): 61-75.

[16] Jabońska, E., Winkowska, M., Winiewska, M., Geurts, J., Zak, D., Kotowski, W. (2020): Impact of vegetation harvesting on nutrient removal and plant biomass quality in wetland buffer zones. - Hydrobiologia. DOI: 10.1007/s10750-020-04256-4.

[17] Jiang, Z., Dai, J., Zhang, T. (2020): Bifurcation analysis of phytoplankton and zooplankton interaction system with two delays. - International Journal of Bifurcation and Chaos 30(03): 331-340.

[18] Kang, X. B., Wang, Y., Zhang, H. (2008): An analysis of bad environmental effects of clogging of the discharging underground river of the Qilu Lake. - Hydrogeology and Engineering Geology 35(6): 121-124 (in Chinese with English abstract).

[19] Kosiba, J., Krztoń, W., Wilk-Wo?Niak, E. (2018): Effect of microcystins on proto- and metazooplankton is more evident in artificial than in natural waterbodies. - Microbial Ecology 75(2): 293-302.

[20] Lettoof, D. C., Bateman, P. W., Aubret, F., Gagnon, M. M. (2020): The broad-scale analysis of metals, trace elements, organochlorine pesticides and polycyclic aromatic hydrocarbons in wetlands along an urban gradient, and the use of a high trophic snake as a bioindicator. - Archives of Environmental Contamination and Toxicology 78(4): 631645.

[21] Li, H., Qi, F., Xie, C. G., Chen, P., Ma, Y. W. (2013): Zooplankton in Bosten Lake: community characteristics and seasonal changes in distribution. - Journal of Fishery Sciences of China 20(4): 832-842.

[22] Li, X. Y., Yu, H. X., Wang, H. B., Ma, C. X. (2019): Phytoplankton community structure in relation to environmental factors and ecological assessment of water quality in the upper reaches of the Genhe River in the Greater Hinggan Mountains. - Environmental Science and Pollution Research 26: 17512-17519.

[23] Ma, C. X., Mwagona, P. C., Yu, H. X., Sun, X. W., Liang, L. Q. (2019): Seasonal dynamics of zooplankton functional group and its relationship with physicochemical variables in high turbid nutrient-rich Small Xingkai Wetland Lake, Northeast China. Journal of Freshwater Ecology 34: 65-79.

[24] Macmillan, G. A., Clayden, M. G., Chetelat, J., Richardson, M. C., Ponton, D. E., Perron, T. (2019): Environmental drivers of rare earth element bioaccumulation in freshwater zooplankton. - Environmental Science and Technology 53(3): 1650-1660. 
[25] Mahlatini, P., Hove, A., Maguma, L. F., Chemura, A. (2020): Using direct use values for economic valuation of wetland ecosystem services: a case of Songore wetland, Zimbabwe. - GeoJournal 85(1): 41-51.

[26] Meng, X., Li, J. (2020): Stability and Hopf bifurcation analysis of a delayed phytoplankton-zooplankton model with Allee effect and linear harvesting. Mathematical Biosciences and Engineering 17(3): 1973-2002.

[27] MEP (2002): China National Environmental Quality Standards for Surface Water. GB3838-2002 (in Chinese).

[28] Munawar, M., Niblock, H., Fitzpatrick, M., Lorimer, J. (2020): Ciliate ecology in the eutrophic Bay of Quinte, Lake Ontario: community structure and feeding characteristics. - Aquatic Ecosystem Health and Management 23(1): 35-44.

[29] Mwagona, P. C., Ma, C. X., Yu, H. X. (2018): Seasonal dynamics of Zooplankton functional groups in relation to environmental variables in Xiquanyan Reservoir, Northeast China. - Annales de Limnologie-International Journal of Limnology 54: 33.

[30] Naumenko, E. N., Telesh, I. V. (2019): Impact of the invasive species Cercopagis pengoi (Ostroumov, 1891) on the structural and functional organization of zooplankton in the Vistula Lagoon of the Baltic Sea. - Russian Journal of Biological Invasions 10(3): 246257.

[31] Ozumchelouei, E. J., Hamidian, A. H., Zhang, Y., Yang, M. (2020): Physicochemical properties of antibiotics: a review with an emphasis on detection in the aquatic environment. - Water Environment Research 92(2): 177-188.

[32] Palijan, G., Balkic, A. G. (2018): Effect of depth on food-web interactions in a thermally stratified floodplain lake following inundation. - River Research and Applications 34(4): 328-337.

[33] Pinheiro-Silva, L., Gianuca, A. T., Silveira, M. H., Petrucio, M. M. (2020): Grazing efficiency asymmetry drives zooplankton top-down control on phytoplankton in a subtropical lake dominated by non-toxic cyanobacteria. - Hydrobiologia 847(10): 23072320.

[34] Qin, J., Wu, X. H., Gao, W. G. (2010): Study on the controlling factors of eutrophic state of Qiluhu Lake. - Journal of Yuxi Normal University 26(12): 26-30 (in Chinese with English abstract).

[35] Research Group of Carcinology, Institute of Zoology, Academia Sinica (1979): Fauna Sinica, Crustacea, Freshwater Copepoda. - Science Press, Beijing (in Chinese).

[36] Rocha, M. I. A., Recknagel, F., Minoti, R. T., Huszar, V. L. M., Kozlowsky-Suzuki, B., Cao, H. (2019): Assessing the effect of abiotic variables and zooplankton on picocyanobacterial dominance in two tropical mesotrophic reservoirs by means of evolutionary computation. - Water Research 149: 120-129.

[37] Romero, O. E., Baumann, K. H., Zonneveld, K. A. F., Donner, B., Fischer, G. (2020): Flux variability of phyto-and zooplankton communities in the Mauritanian coastal upwelling between 2003 and 2008. - Biogeoences 17(1): 187-214.

[38] Saler, S., Bulut, H., Karakaya, G. (2019): Zooplankton of Çat Dam Lake (MalatyaTurkey) with a new record for Turkish rotifers Lecane intrasinuata (Olofsson, 1917). Iranian Journal of Fisheries Sciences 18(1): 199-204.

[39] Setubal, R. B., Riccardi, N. (2020): Long-term effects of fish biomanipulation and macrophyte management on zooplankton functional diversity and production in a temperate shallow lake. - Limnology 21: 305-317.

[40] Sharma, B. K., Sharma, S. (2020): Zooplankton diversity of a subtropical reservoir of Meghalaya, Northeast India with remarks on spatial and temporal variations. - Opuscula Zoologica Budapest 50(1): 67-86.

[41] Shi, Y. Q., Sun, S., Zhang, G. T., Wang, S. W., Li, C. L. (2015): Distribution pattern of zooplankton functional groups in the Yellow Sea in June: a possible cause for geographical separation of giant jellyfish species. - Hydrobiologia 754: 43-58. 
[42] Sordino, P., D’Aniello, S., Pelletier, E., Wincker, P., Nittoli, V., Stemmann, L. (2020): Into the bloom: molecular response of pelagic tunicates to fluctuating food availability. Molecular Ecology 29(2): 292-307.

[43] Sun, X., Chai, F. Y., Mwagona, P. C., Shabani, I. E., Hou, W. J., Li, X. Y., Yu, H. X. (2019): Seasonal variations of zooplankton functional groups and relationship with environmental factors in a eutrophic reservoir from cold region. - Applied Ecology and Environmental Research 17(4): 7727-7740.

[44] Taddeo, S., Dronova, I. (2020): Landscape metrics of post-restoration vegetation dynamics in wetland ecosystems. - Landscape Ecology 35(2): 275-292.

[45] Tapia, A. P., Genzano, G. (2019): Seasonal succession of gelatinous zooplankton (medusae and ctenophores) from Mar Del Plata Harbor, Argentina (SW Atlantic Ocean). - Ecologia Austral 29(3): 339-351.

[46] Tavernini, S., Mura, G., Rossetti, G. (2005): Factors influencing the seasonal phenology and composition of zooplankton communities in mountain temporary pools. International Review of Hydrobiology 90(4): 358-375.

[47] Tsai, C. P., Huang, C. M., Yuan, C. S., Yang, L. (2020): Seasonal and diurnal variations of greenhouse gas emissions from a saline mangrove constructed wetland by using an in situ continuous GHG monitoring system. - Environmental Science and Pollution Research 27(13): 15824-15834.

[48] Tutasi, P., Escribano, R. (2019): Zooplankton diel vertical migration and downward C flux into the oxygen minimum zone in the highly productive upwelling region off northern Chile. - Biogeosciences Discussions 1-31.

[49] Uzundumlu, S., Buyukates, Y., Ates, A. S. (2020): Potential impacts of a waste reception facility on stable isotope composition of zooplankton and particulate organic matter in the dardanelles. - Polish Journal of Environmental Studies 29(5): 1-8.

[50] Velip, D. T., Rivonker, C. U. (2018): Trophic dynamics of few selected nearshore coastal finfishes with emphasis on prawns as prey item. - Journal of Sea Research 136(1): 28-36.

[51] Wang, J. J. (1961): Fauna Sinica, Crustacea, Freshwater Rotifera. - Science Press, Beijing (in Chinese).

[52] Wang, H., Liu, L. P., Li, Y. P. (2016): Relationship between zooplankton community structure and environmental factors in spring and summer in Dianchi Lake. Environmental Science Survey 35(6): 10-16 (in Chinese with English abstract).

[53] Wu, Z. B., Liu, A. F., Zhang, S. Y., Cheng, S. P., Wu, X. H. (2008): Short-term effects of drawing water for connectivity of rivers and lakes on zooplankton community structure. Journal of Environmental Sciences 20(4): 419-423.

[54] Wu, Q. M., Zou, H. F., Ma, J. Z. (2014): Nest site selection of white-naped crane (Grus vipio) at Zhalong National Nature Reserve, Heilongjiang, China. - Journal of Forestry Research 25(4): 947-952.

[55] Wu, P., Kainz, M., Åkerblom, Staffan, Bravo, A. G., Sonesten, L., Branfireun, B. (2019): Terrestrial diet influences mercury bioaccumulation in zooplankton and macroinvertebrates in lakes with differing dissolved organic carbon concentrations. Science of The Total Environment 669: 821-832.

[56] Yuzhan, Y., Ping, N., Yangchun, G., Wei, X., Yan, Z., Aibin, Z. (2018): Geographical distribution of zooplankton biodiversity in highly polluted running water ecosystems: validation of fine-scale species sorting hypothesis. - Ecology and Evolution 8(10): 48304840 .

[57] Zaghloul, A. E. R., Khairy, H. M., Hussein, N. R. (2020): Assessment of phytoplankton community structure and water quality in the eastern harbor of Alexandria, Egypt. - The Egyptian Journal of Aquatic Research 46(2): 145-151.

[58] Zamora-Barrios, C. A., Nandini, S., Sarma, S. S. S. (2019): Bioaccumulation of microcystins in seston, zooplankton and fish: a case study in Lake Zumpango, Mexico. Environmental Pollution 249: 267-276. 


$$
-2858 \text { - }
$$

[59] Zhang, J., Shu, X., Zhang, Y., Tan, X., Zhang, Q. (2020): The responses of epilithic algal community structure and function to light and nutrients and their linkages in subtropical rivers. - Hydrobiologia 847(3): 841-855.

[60] Zou, H., Dong, H., Kong, W., Jianhua, M. A., Liu, J. (2010): Characterization of 18 polymorphic microsatellite loci in the red-crowned crane (Grus japonensis), an endangered bird. - Animal Science Journal 81(4): 519-522. 